\title{
Tumour production of alkaline phosphatase in a patient with giant-cell carcinoma of bronchus
}

\author{
J. M. PFEFFER AND P. G. I. STOVIN \\ From Papworth Hospital, Papworth Everard, Cambridge, Cambs CB3 8RE
}

Pfeffer, J. M., and Stovin, P. G. I. (1978). Thorax, 33, 261-264. Tumour production of alkaline phosphatase in a patient with giant-cell carcinoma of bronchus. A patient with a giant-cell carcinoma of the bronchus was found to have a raised serum alkaline phosphatase without any evidence of bone or liver involvement. After necropsy the excised tumour was found to be producing alkaline phosphatase. The alkaline phosphatase found in the serum during life was heat-labile but that in the tumour was heat-stable. The significance of this is unknown.

Many cases have been recorded of tumours producing chemical substances with biological activity when the normal tissue from which the tumour arises would not normally produce these substances (Lipsett, 1965). These chemicals are normally synthesised by other cells. It has been suggested (Greene and Sussman, 1973) that their synthesis is due to the derepression of the genome accompanying neoplastic transformation. Thus polypeptides synthesised ectopically in neoplastic cells are products of the same gene as the one synthesised in the normal cell of origin. One such protein, probably a glycoprotein (Fosset et al., 1974), that has been associated with human neoplasms is alkaline phosphatase (Fishman et al., 1968b).

\section{Case report}

A 63-year-old man with a smoking history of one cigarette per day and one ounce of pipe tobacco per day, but who had stopped smoking six weeks before admission, had recently had a prostatectomy followed by acute renal failure. He had been a bronchitic for 10-15 years with sputum but no real dyspnoea. In the two months before he was seen at the chest clinic he had had two attacks of wheezing without cough or fever. $\mathrm{He}$ also complained of giddiness on going uphill, dyspnoea, and lethargy. A chest radiograph (Fig. 1) showed a lobulated mass superimposed on the right cardiac border and a mass above the right hemidiaphragm. The heart was enlarged in its transverse diameter.

The patient had a hypochromic anaemia
(Hb $7 \mathrm{~g} / \mathrm{dl}$ ), the marrow picture showing dyserythropoietic anaemia. The alkaline phosphatase on admission was found to be raised (Fig. 2). It was nearly all heat-labile, its activity ceasing after heating to $58^{\circ} \mathrm{C}$ for 20 minutes. Plasma cortisol levels were slightly raised to $883 \mathrm{nmol} / 1(32 \mu \mathrm{g} /$ $100 \mathrm{ml})$ at 0900 hours and $497 \mathrm{nmol} / 1(18 \mu \mathrm{g} /$ $100 \mathrm{ml}$ ) at 2215 hours but still showed the diurnal variation. Liver scan, bone scan, and skeletal radiological survey showed no abnormalities.

The alkaline phosphatase rose over the next few weeks (Fig. 2) in parallel with the radiological size of the tumour. A biopsy through a limited right thoracotomy showed, histologically, a giant-cell carcinoma of the lung (Fig. 3). He received 2100 rads from a Cobalt 60 source given in six divided doses over 11 days. The alkaline phosphatase dropped dramatically within eight days (Fig. 2) without any radiological change in the size of the tumour. Five months later he was briefly admitted to hospital with slight jaundice and anaemia. The serum alkaline phosphatase was twice found to be greatly raised at $1112 \mathrm{IU} / 1$ and $868 \mathrm{IU} / 1$. One month later he died at home.

Necropsy revealed a large mass of necrotic tumour in the anterior half of the middle lobe with smaller nodules of secondary carcinoma in the right upper and lower lobes and one large mass in the right diaphragm. Secondary nodules were present in the right hilar and paratracheal nodes. The total mass of tumour tissue was approximately $900 \mathrm{~g}$, and there were no secondary deposits in the vertebral bodies, ribs, or liver. A heat-stable alkaline phosphatase was demonstrated in tumour 


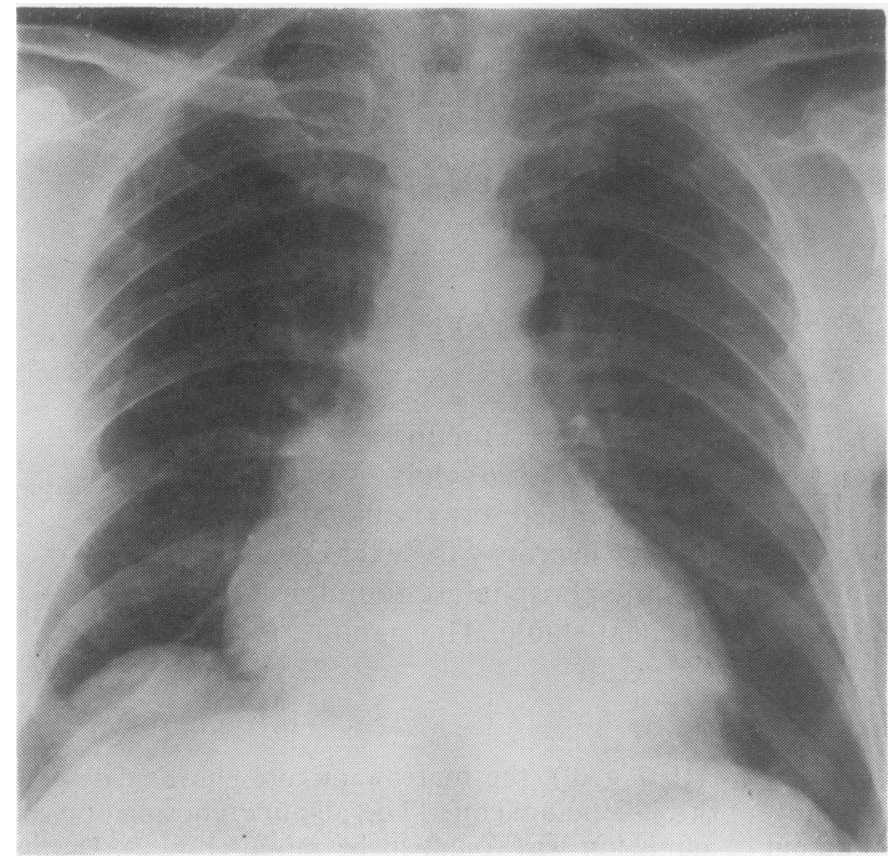

Fig. 1 Chest radiograph showing lobulated mass superimposed on right cardiac border and mass above right hemidiaphragm.

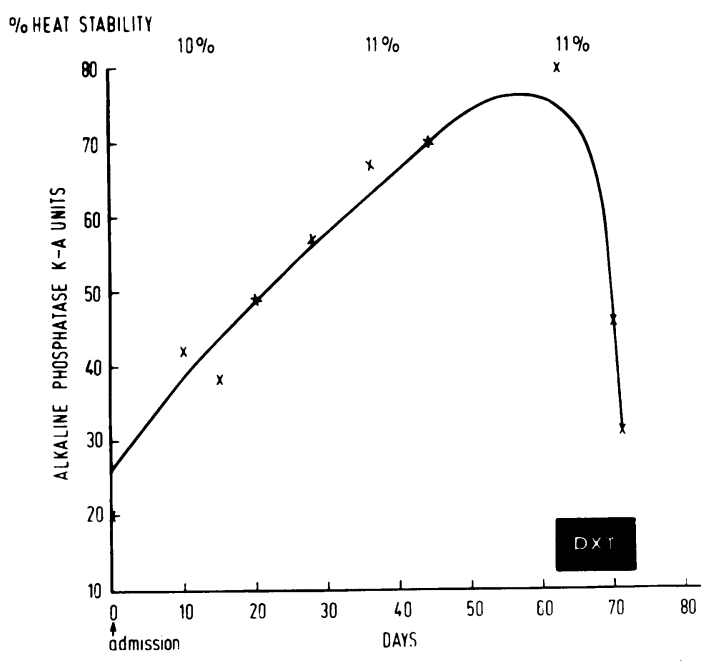

Fig. 2 Serum alkaline phosphatase at approximately 10-day intervals. The striking fall after radiotherapy (DXT) and the constant level of heat stability are also shown.

cells from unfixed tumour tissue obtained 20 hours after death (Fig. 4).

\section{Discussion}

The practical relevance of this case is that a raised alkaline phosphatase found on routine screening of patients with tumours is normali taken to imply bony or hepatic metastases. How ever, as shown in this case, the primary tumour itself may be the source of the raised serum alkat line phosphatase. In one of the early reports (Fishman et al., 1968a) of cases in which alkat line phosphatase was produced from tumour tio sues, the alkaline phosphatase (Regan Isoenzyme) was found to be similar to that produced by the placenta and was heat-stable. However, anothe्r. type of alkaline phosphatase produced by a tumour has been reported (Timperley, 1968), which is heatlabile. The alkaline phosphatase produced by our patient seems to differ from the other two in the the tumour alkaline phosphatase was heat-stabe whereas that in the serum was nearly all heaf labile. The alkaline phosphatase recorded in the serum apparently originated in the tumour b\& cause bone and liver were normal both on clinicat tests and at necropsy, and the alkaline phosphatase dropped dramatically after radiotherapy. It is dif cult to suggest a reason why our alkaline pho\$ phatase isoenzyme should have this inconsistent reaction to heat. As two different active sites have been shown to exist in calf intestinal alkaline pho phatase (Chappelet-Tordo et al., 1974), it is possibe that the tumour produced two isoenzymes and that one type predominated and was more radie sensitive. Alternatively, possibly the heat-stable isoenzyme from the tumour was converted elsez 


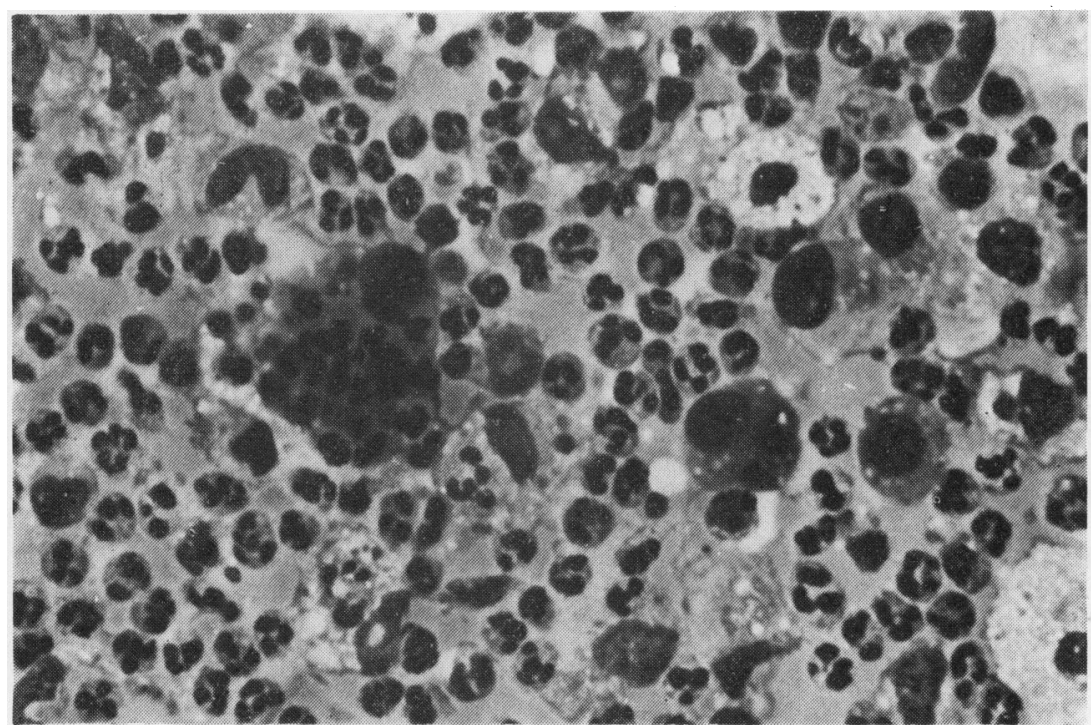

Fig. 3 Biopsy specimen of tumour showing giant-cell carcinoma, one cell containing numerous neutrophils. Impression smear (Leishman stain $\times 160)$.

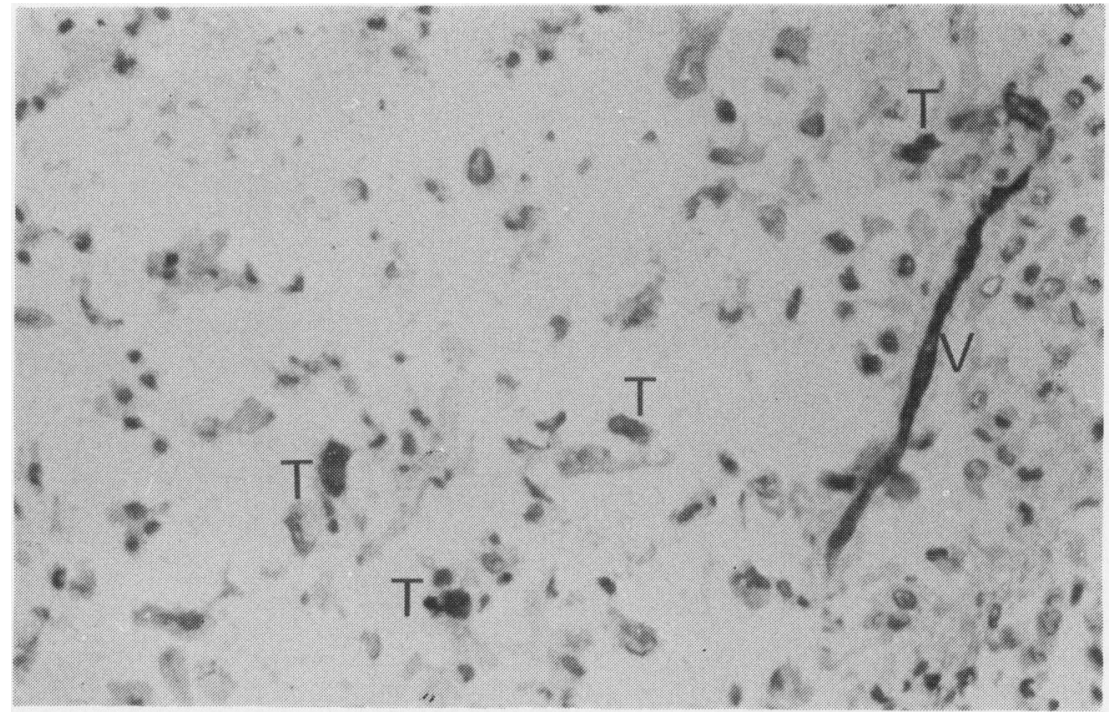

Fig. 4 Tumour at necropsy. Gomori alkaline phosphatase. Vascular endothelium $(V)$ and tumour cells $(T)$ show positive reaction. After heating, only tumour cells gave a positive reaction $(\times 125)$. 
where into the heat-labile isoenzyme. A third possibility is that the serum alkaline phosphatase came in part from the neutrophils (Fig. 3) ingested by the tumour cells.

We thank Mrs. R. Cooper for the photographs.

\section{References}

Chappelet-Tordo, D., Fosset, M., Iwatsubo, M., Gache, C., and Lazdunski, M. (1974). Intestinal alkaline phosphatase. Catalytic properties and half of the sites reactivity. Biochemistry, 13, 1788-1795.

Fishman, W. H., Inglis, N. R., Green, S., Anstiss, C. L., Gosh, N. K., Reif, A. E., Rustigian, R., Krant, M. J., and Stolbach, L. L. (1968a). Immunology and biochemistry of Regan isoenzyme of alkaline phosphatase in human cancer. Nature, 219, 697-699.

Fishman, W. H., Inglis, N. R., Stolbach, L. L., and Krant, M. J. (1968b). A serum alkaline phos- phatase isoenzyme of human neoplastic cell origin $\underset{\overline{\mid}}{\overrightarrow{3}}$ Cancer Research, 28, 150-154.

Fosset, M., Chappelet-Tordo, D., and Lazdunski, M등 (1974). Intestinal alkaline phosphatase. Physica properties and quaternary structure. Biochemistry $13,1783-1788$.

Greene, P. J., and Sussman, H. H. (1973). Structura觔 comparison of ectopic and normal placental alkaline phosphatase. Proceedings of the National Academy of Sciences of the United States of America, 70 2936-2940.

Lipsett, M. B. (1965). Humoral syndromes associate with cancer. Cancer Research, 25, 1068-1073.

Timperley, W. R. (1968). Alkaline-phosphatase secreting tumour of lung. Lancet, 2, 356.

Requests for reprints to: $\operatorname{Dr}$ P. G. I. Stovin Papworth Hospital, Papworth Everard, Cambridge CB3 8RE. 